\title{
Impact of junk food on health
}

\author{
Shaik Ali Hassan ${ }^{*}$, Sumit Bhateja ${ }^{2}$, Geetika Arora ${ }^{3}$, Francis Prathyusha ${ }^{4}$ \\ ${ }^{1}$ Dental Surgeon, ${ }^{2} \mathrm{HOD},{ }^{3}$ Reader, ${ }^{4} \mathrm{MDS},{ }^{1}$ Dept of Dentistry, ${ }^{1,4} \mathrm{Francis}$ Maxillofacial and Dental Clinic, India, ${ }^{2}$ Manav Rachna Dental \\ College, Haryana, India, ${ }^{3}$ Inderprastha Dental College and Hospital, Uttar Pradesh, India
}

\section{*Corresponding Author: Shaik Ali Hassan}

Email: alishaikhassan@gmail.com

\begin{abstract}
Junk food refers to fast food, easy to make and easy to consume. Their low nutritional value and just lay down fat in it cause adverse effects on Health of consumer. The term 'Junk food' was created by Michael Jacobson, director of the Center for Science in 1972 in common interests who want to improve public concern about problem foods with high calorific value and low a nutritional value. Junk food contains high levels of fine sugar, white flour, trans fats, polyunsaturated fats and fat salt various food additives such as monosodium glutamate (MSG) and tartrazine, and the lack of protein, vitamins and fiber. The junk food advertising is also play a great role in junk food's popularity. But it should be avoided, because of lack of energy, high cholesterol and poor concentration. It causes a lot of harmful effect on the body like obesity, diabetes, heart disease and various types of skin cancers. In this review article we will see what are different types of junk food, how it attracts most of people and how to reduce the consumption of junk food.
\end{abstract}

Keywords: Junk food, Cholesterol, Fat, Salt, Sugar, Obesity, Concentration, Advertisement.

\section{Introduction}

Junk food refers to fast food, easy to make and easy to consume. Their low nutritional value and just lay down fat in it cause adverse effects on Health of consumer. The term 'Junk food' was created by Michael Jacobson, director of the Center for Science in 1972 in common interests who want to improve public concern about problem foods with high calorific value and low a nutritional value. Junk food contains high levels of fine sugar, white flour, trans fats, polyunsaturated fats and fat salt various food additives such as monosodium glutamate (MSG) and tartrazine, and the lack of protein, vitamins and fiber. Junk food is popular because of their simplicity produce, consume, their tastes and have a long shelf life which may not require refrigeration. ${ }^{1}$ In the United Kingdom of the food standards body does not use the term Junk food food dan describe' HFSS '(high in fat, sugar or salt). They claimed that having food can form part of a balanced diet, but research suggests that a child's diet contains too much fat (especially trans fats) salt and sugar. ${ }^{2}$ The availability of junk food and snacks at low prices and marketing strategies adopted by the like food manufacturers have triggered evolution whereby, food consumption requires both structural and formal meal preparation., Seems to have engulfed every age, every race and the latest newcomer on the stage were children, school will be in certain. ${ }^{5}$ Obesity accounts for 300,000 deaths in the US alone. Research junk food and fast food the restaurant has been found that there is a direct the relationship between the numbers of fast food restaurant located in the local area and the rate of obesity. ${ }^{6}$ India is no exception to this is changing fast trend. Indian fast food industry's growth by 40 percent per year. Statistics place India at 10 Place in a fast food per capita spending figures with $2.1 \%$ of the total annual expenditure spending. According to the National Sample Survey Organization (NSSO) survey in 2005 issued by the Delhi government, the living in Delhi spent Rs. 371, on average, on food and beverage per month are processed. They spent Rs. 290 on vegetables and around one-third of the fruit. The total value of junk food consumed in India in 2003 was around Rs. 41,000 crore; that, in rural areas accounted for for a little more than Rs. 22,000 crore, as published in an article in the newspaper by Sudhanshu Ranade The Business Line on July $13,2005 .^{7}$

\section{Problems with junk food Increased fat}

Junk foods, for example, burgers, pizza, seared chicken and chips generally heaps of soaked fats, an excess of immersed fat in diet will make individuals put on weight and large being overweight is a hazard to the wellbeing of heart and causes other infection.

\section{Increased salt content}

Junk regularly have an excess of salt there is a great deal of salt as of now in food, for example, bread, breakfast oats and rolls. So individuals are getting more salt than they need when they eat junk food an excess of salt is undesirable for healthy life.

\section{Increased sugar content}

Soda pops, cordials, bread rolls, cakes and lollipop likewise have heaps of sugar that is the thing that makes them taste excessively great yet an excess of sugar makes individuals fat, decays the teeth, is awful for the blood and may cause other disease. ${ }^{8}$ Junk food has some of beneficial things that the body requirements for good wellbeing as the body needs some salt, fat and sugar for vitality to consume while we play and work be that as it may a lot of fat, salt and sugar is terrible for wellbeing. Individuals tend to settle their dinners by devouring inexpensive food to spare time. Scientists have indicated that junk food may cause dyslexia, ADHD (consideration shortfall hyperactivity issue) what's more, might be chemical imbalance. ${ }^{9,10}$ 
Why is junk food more preferred?

Junk food contains whatever is fast, delectable, helpful and in vogue. Astute junk food advertising and the bait of comfort in addition to taste drag individuals to junk food addiction. Following factors for the most part makes it engaging:

1. Time-Junk food addiction is so high due to its effortlessness. They are simple to get ready and ready to devour inside no time.

2. Tasty food-Great taste additionally, is another significant motivation to a degree that impacts to choose junk food. This taste is accomplished inferable from luxurious utilization of oils, salts as well as sugar.

3. Attractive-Packing of such foods has appealing appearance by adding food additives and hues in addition to improvement in flavor.

4. Advertisement- Advertising ${ }^{11}$ has a significant job in drawing in the general population, especially kids and adolescents ${ }^{12}$ to the junk food selling joints.

\section{Why junk food should be avoided? ${ }^{13}$ \\ Lack of energy}

This is known as transient adverse impact coming about because of eating junk food as junk food don't give the fundamental supplements (like nutrients, protein and fibers) despite the fact that they can especially doing the trick, people groups feel debilitated.

\section{Reduction of concentration}

This is another consequence of junk food propensity. These are followed to impact in quick and medium term periods when people groups have a lavish junk supper wealthy in oil they feel tired and neglect to think.

\section{Increased cholesterol}

Over continued times of junk food eating blood flow drop because of fat collection, absence of crucial oxygen, supplements and protein especially can stale their synapses briefly aside from shaping plaques and contracting conduits cholesterol likewise influences liver where it is processed. High cholesterol because of junk food and diet strains liver harming it at last. This is long haul impact.

\section{Heart disease}

Junk food diet is a significant reason for heart maladies (Myocardial localized necrosis) because of plaque development in corridors which requests heart to invest additional push to siphon blood on the downstream, on the upstream there is absence of returning blood to heart, this makes two harms heart-heart exhausts because of consistent additional exertion and it endure in oxygen gracefully.

\section{Lack of nutrition}

The healthy benefit of junk food is around one on a size of 1 to 10 , which is the least. The healthy benefit is lost during the time spent creation the junk food so engineered nutrients and minerals are added to repay it, however they are bad contrasted with regular nutrients and minerals. Common phytochemicals are absent in junk food which absorbs the free radicals to forestall sickness.

\section{High chemical content}

Junk food have loads of compound additives which are most certainly not valuable to body, things resemble counterfeit shading and additives. MSG and tartrazine is in practically all kind of junk food and a wide range of clinical examinations have uncovered that MSG causes corpulence and of other terrible things. All the methods used to process the junk food - canning, drying out and freezing, practically obliterate the kind of food so synthetic concoctions under the pretense of 'regular flavor' have been added to lacquer the flavor, while shading additives are added to make food new. It may make the food look and taste better however it is unsafe to our bodies.

\section{Reduced oxygen supply}

Junk food is wealthy in fat so collection of fat can takes place in bronchioles so oxygen flexibly tends to diminished in body which can cause some respiratory issue.

\section{Tips to reduce intake of junk food}

1. Junk food and youngster's bizarre liking to one another. Try not to let youngsters to get habituated to junk food. Inquire them to maintain a strategic distance from junk food accessible in school/school container. ${ }^{14,15}$

2. Dispensing with the enticement for junk food is one approach to maintain a strategic distance from it. Keeping great food close by and having dinners exactly on schedule may help toward this path. Controlling the allurement for junk food is a lot simpler at that point controlling liquor abuse.

3. Controlling youngsters from eating junk food in schools is another progression that helps in a long haul. Schools administrator alongside guardians has an obligation to teach kids about junk foods in schools. ${ }^{16,17}$

\section{Alternatives of junk food}

1. Beef, Hamburg -Grilled chicken.

2. Fried appetizers- Salad.

3. Pasta or potatoes- Vegetables.

4. Shakes or soda- Orange juice or water.

5. Chowder or cream soup- Vegetable soup.

6. Bologna, salami, ham- Turkey breast on oatmeal bread.

7. Regular dressing, mayonnaise, oil- Low fat salad dressing.

8. White bread or sub roll- Oatmeal, Syrian or Wheat bread. ${ }^{18,19}$

\section{Reducing junk food mainly in children}

Since junk food and youngsters have an odd proclivity to one another, attempt to keep away from youngsters to get habituated to such foods.

1. Controlling youngsters from eating junk foods in schools is another progression that helps in a long term. School administration alongside guardians has a joined 
obligation to teach youngsters about staying away from junk foods in school premises. ${ }^{20}$

2. Junk food - the name itself is enticing enough. Disposing of the enticement is one way to stay away from it. Keeping great food close by and having dinners exactly on schedule absolutely helps in this bearing. ${ }^{21}$

3. Creating mindfulness for wellness will surely isolated junk food and great eating routine. As cited in an article Wanted youngster lock for junk food in The Telegraphdistributed on sixteenth February 2009, Calcutta Edition by Varuna Verma But instructing guardians about the unsafe impacts of junk food could likewise assist youngsters with kicking the propensity.$^{22}$

4. The World Consumer Rights Day on March 15 will start a crusade against the promoting of undesirable foods to youngsters. Among school youngsters, numerous vital thoughts can be consolidated in schools, for example, Bring organic product at school ${ }^{23,24}$ which plans to chop down at junk food utilization and its addiction advancing sound food propensities among them. A portion of the school-based exploration and activities can open entryways for recognizing promising methodologies to create fruit and vegetable environment among understudies in school settings. ${ }^{25-27}$

\section{Conclusion}

Junk foods have absolutely cut up the Third World because of globalization. It is a necessary piece of life in the created and furthermore the creating scene, and accompanying it is a gigantic increment in weight and related issues. The way to eating these junk foods is balance, incidental utilization and ideally in little segments. It isn't difficult to win war with junk foods against solid foods.

\section{Source of Funding}

None.

\section{Conflict of Interest}

None.

\section{References}

1. http://www.diet policy.com/diet-articles/junk food-facts-html.

2. http://www.wikipedia/org./wiki/junk-food-html.

3. Solomons NW, Gross R. Urban nutrition in developing countries. Nutr Rev 1995; 53(4): 90-5.

4. Holmboe-Ottesen G. Global trends in food consumption and nutrition. Tidsskr Nor Laegeforen 2000; 120(1):78-82.

5. Fitzpatrick M. Junk food. Lancet 2004; 363:1000.

6. A.B Harrins, G.V.Robbins,"Nutrition in catering"; William hinmanpublishers, London, page no; 173-5.

7. Baronowski T. Families and health action. Handbook of health behaviourresearch, personal and social determinants. Plenum press, New York 1997; 179-205.

8. http://www.nutritionexploration.org/kids/nutrition-main-asp.

9. http://EzineArticles.com/?Expert=SusanneMyers.

10. http://EzineArticles.com/?Expert=BrendaWillams.

11. Dixon HG, Scully ML, Wakefield MA, White VM, Crawford DA. The effects of television advertisements for junk food versus nutritious food on children's food attitudes and preferences. Soc Sci Med 2007; 65(7):1311-23.
12. Fister K. Junk food advertising contributes to young Americans obesity. BMJ 2005; 331(7530):1426.

13. http://ezinearticles.com/?Expert=MarkCorner.

14. http://EzineArticles.com/?Expert=SueMerriam.

15. http://www.healthcare.com/topics/howtoavoid-4826-html

16. Taylor JP, Evers S, McKenna M. Determinants of healthy eating in children and youth. Can J Public Health. 2005;(9):S20-6, S22-9.

17. Zhu SP, Ding YJ, Lu XF, Wang HW, Yang M, Wang JX, et al. Study on factors related to top 10 junk food consumption at 8 to 16 years of age, in Haidian District of Beijing. Zhonghua Liu Xing Bing Xue Za Zhi. 2008;29(8):757-62.

18. Bailey R, Wise K, Bolls P. How avatar customizability affects children's arousal and subjective presence during junk foodsponsored online video games. Cyberpsychol Behav 2009; 12(3):277-83.

19. Coon KA, Tucker KL. Television and children's consumption patterns. A review of the literature. Minerva Pediatr.2002; 54(5):423-36.

20. Jackson P, Romo MM, Castillo MA, Castillo-Durán C. Junk food consumption and child nutrition. Nutritional anthropological analysis. Rev Med Chil 2004;132(10):1235- 42.

21. Pérez Rodrigo C, Aranceta J, Brug H, Wind M, Hildonen Ch, Klepp KI, et al. School-based education strategies to promote fruit and vegetable consumption: the Pro Children Project. Arch Latinoam Nutr 2004;54(2):14-9.

22. Guenther PM, Reedy J, Krebs-Smith SM. Development of the Healthy Eating Index-2005. J Am Diet Assoc. 2008;108(11):1896-901.

23. McNamara JR, Green JP. Decreasing junk-food consumption through the use of self-management procedures: A case study. Psychol Rep. 1991;69(1):19-22.

24. Bull D. Junk food: carving up the Third World. Nurs Mirror 1980;151(25):38-9.

25. Panunzio MF, Antoniciello A, Ugolini G, Dalton S. Bring fruit at school: promotion of healthy food habit in primary schoolchildren. Ann Ig 2009;21(4):403-7.

26. French SA, Wechsler H. School-based research and initiatives: fruit and vegetable environment, policy, and pricing workshop. Prev Med. 2004; 39(2):S101-7.

27. Scaglioni S, Salvioni M, Galimberti C. Influence of parental attitudes in the development of children eating behaviour. $\mathrm{Br} J$ Nutr. 2008; 99(1):S22-5.

How to cite: Hassan SA, Bhateja S, Arora G, Prathyusha F. Impact of junk food on health. J Manag Res Anal. 2020;7(2):57-9. 